Øivin Andersen

\title{
Fagspråk som forskningsdisiplin (1. del)
}

\begin{abstract}
This article deals with the object of study for LSP. After stressing the general importance of studying LSP (Language for Specific Purposes) (section 2), attention is focused on basic methods, models and definition types used in attempts at drawing a line of demarcation between LSP and LGP (Language for General Purposes) (section 3). Four alternative approaches to the relationship between LSP and terminology are discussed in section 4 . In section 5 the object of study is discussed in more detail. The concept subject field is seen as being related to the concepts tacit knowledge and communicative competence. The article concludes that the most fruitful study of LSP is the themes or subect matter of texts.
\end{abstract}

\section{Innledning}

I de siste 50 årene har fenomenet fagspråk (FS) i stadig stigende grad blitt fokusert på som forskningsdisiplin og studieobjekt. De konklusjoner og "programerklæringer" man har kommet frem til i tidenes løp er mange og tildels svært uforenlige. Jeg skal ikke prøve å gi noen fullstendig oversikt over denne mangslungne faghistorien, men i stedet ta opp noen få spørsmål, som jeg anser som grunnleggende, til drøfting:

1. Hvorfor er det viktig å studere FS som fenomen?

2. Hvilket forhold er det mellom FS og allmennspråket (AS)?

3. Hvilket forhold er det mellom FS og terminologi (TL)?

4. Hva er FS's studieobjekt?

Artikkelen munner ut i en drøfting av FS som studieobjekt, og tar opp begrepene fagområde og tematikk i sammenheng med informasjons- og dokumentasjonslæren, samt en diskusjon av begrepene økonomi og entydighet i FS-sammenheng.

\section{Hvorfor studere fagspråk som fenomen?}

Det er en kjent sak at det språket man bruker for å beskrive virkeligheten med, er tilpasset den erfaringsverden man lever i. Dette ser vi tydeligst på det leksikalske nivå. Det som leksikaliseres i forskjellige språk varierer ganske mye, og forskjellene øker jo større avstand det er mellom språksamfunnenes sosiale og kulturelle systemer. Et språks leksikon sier oss derfor noe om et språksamfunns kulturelle og sosiale forhold. Hvis et 
fenomen er fremtredende i et språksamfunn, resulterer dette som regel i leksikalsk fininndeling. Klassiske eksempler er eskimoenes mange ord for snø, avhengig av snøens konsistens, og vietnamesernes mange ord for ris, avhengig av hvilket produksjonsstadium den befinner seg på (ris som såkorn, tresket ris, kokt ris etc) (jf Thompson 1965).

Disse leksikalske fininndelingene er imidlertid ord/uttrykk som alle medlemmene av dette språksamfunnet er innforstått med.

Men det moderne samfunnet har en tendens til å utvikle spesielle delsektorer av språksamfunnets leksikon som ikke alle språkbrukerne forstår. Grunnene til det kjenner vi: spesialiseringen og arbeidsdelingen i samfunnet øker stadig, og språket må tilpasse seg en ny virkelighet, nye erkjennelser som gir opphav til nye begreper som må kommuniseres.

Det er en kjensgjerning at demokratiet er avhengig av at mest mulig informasjon tilflyter flest mulig mennesker. Informasjonstilgjengeligheten i samfunnet er da også et erklært mål i norsk politikk:

"I en tid da vi tar sikte på at stadig flere skal ta aktivt del i styringen av samfunnet er det viktig at allmennheten får de best mulige bakgrunnsopplysninger. Det er derfor viktig at forskningsresultatene blir bearbeidet med sikte på allmenn tilgjengelighet" (Stortingsmelding nr 35 (1975-76, 77).

Dette må skje via språklig kommunikasjon.

Spesialiseringen av fagkunnskapen fører uvegerlig til fremveksten av fagspråk med alle dets konsekvenser på godt og vondt. Den offentlige debatt trekker i stadig større grad veksler på ulike fagspråksvarianter. Vi kan nevne sentrale områder som edb, oljeteknologi, medisin, jus, romfart, miljøvern og genteknologi. Hvis målsettingen i stortingsmelding nr 35 skal oppfylles, er det viktig å se nærmere på disse fagspråkene, hvordan de fungerer overfor allmennspråket, og hvordan de fungerer innad i fagmiljøene.

Når det gjelder det sistnevnte spørsmålet vet vi at fagspråk kan fungere som en gruppeindikator for den gruppen som tilhører et fagmiljø. Dette kan i visse tilfelle føre til en utvikling som går i stikk motsatt retning av det som stortingsmelding nr 35 legger opp til: Fagspråksvarianten for gruppen kan bli hermetisert ved at det dannes bevisste kommunikasjonsbarrierer mellom denne gruppen og allmennspråket. Man kan for eksempel immunisere seg fra kritikk utenfra ved å manipulere med fagspråk (jf Beaugrande 1984, 1987a, 4). Det har derfor vært reist en del kritikk mot det man kaller uberettiget bruk av fagspråk og terminologi. Når det er sagt må det imidlertid legges til at spesialisert kommunikasjon krever spesialiserte uttrykksmuligheter. 
Vi står med andre ord overfor et dilemma: Kravet om at språket skal være allemannseie, og dermed forståelig for alle, kolliderer med kravet om entydig kommunikasjon og kommunikative behov på spesielle områder. Men spesialisering og fagspråk er nødvendig for samfunnets utvikling. I lys av dette dilemmaet er det både viktig og nødvendig å studere fagspråk.

\section{Forholdet mellom fagspråk (FS) og allmennspråk (AS)}

I likhet med dialekt- og sosiolektforskning prøver FS-forskningen i stor grad å relatere sitt domene til et kollektivt språkbegrep; en sosial størrelse som er felles for alle normalt utrustede språkbrukere i et språksamfunn (et langue). Selv om det fremheves at dialekter må studeres på sine egne premisser, gir ikke dialektbegrepet noen mening hvis ikke dialektene kan subsummeres under en samlekategori språk som en fellesnevner for alle dialektene. Begrepet dialekt impliserer altså dialekt av et språk, enten i kollektiv forstand eller sett på som et mengde-begrep. Det kollektive språkbegrepet innebærer et syn på språket som en sosial institusjon bestående av et sett av normer. Normene er felles for en gruppe mennesker, et kollektiv, som identifiserer seg med disse normene. I det mengdeteoretiske språkbegrepet ligger det ingen påstander om normer som binder språket sammen. Dette begrepet sier kun at det eksisterer et generelt begrep språk, og at det består av (i vår kontekst) tre sett av variabler: teknolekter, dialekter og sosiolekter. I utgangspunktet har disse variablene ingen andre egenskaper enn å være elementer i det mer generelle begrepet språk. Det mengdeteoretiske språkbegrepet påstår dermed mindre enn det kollektive.

I analogi med dette har FS-forskningen tatt i bruk begrepet teknolekt for å karakterisere en variant av kollektivbegrepet fagspråk. Et problem med denne analogien er at kollektivbegrepet fagspråk (som utgjør mengden av teknolekter) da på en eller annen måte må relateres til et allmennspråk, et langue. Forenklet kan man illustrere det slik:
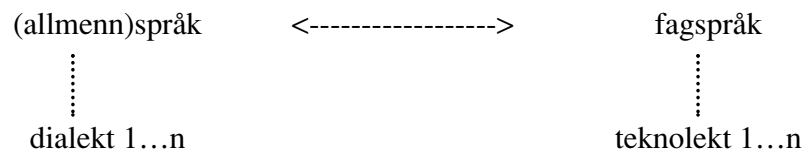

For å kunne danne oss et bilde av hvordan forholdet mellom FS og AS søkes definert, må vi se nærmere på hvilke metoder, hvilke modeller og hvilke definisjonstyper som har vært (og fremdeles er) fremtredende i fagspråksforskningen når det gjelder avgrensningen overfor AS. 


\subsection{Metoder}

Jeg vil her skissere opp fire vanlige metoder: den analytiske, den syntetiske, den semasiologiske og den onomasiologiske. De fire metodene ekskluderer ikke hverandre i praktisk forskning, selv om den analytiske og den syntetiske på den ene siden, og den semasiologiske og den onomasiologiske på den andre siden, ofte fremstilles som logisk komplementære. Tvert imot, de kombineres ofte, avhengig av hvilket aspekt som studeres.

Den analytiske metode går fra større til mindre enheter ved oppdeling (analyse). Denne metoden er svært vanlig i tekstlingvistisk orienterte innfallsvinkler til FS. Et typisk eksempel er Hoffmanns kumulative tekstanalyse (Hoffmann 1983). Hans utgangspunkt er fagteksten (et begrep vi kommer nærmere inn på senere):

Sie $<$ fagspråksforskningen, $\varnothing \mathrm{A}>$ geht vielmehr davon aus, dass die linguistische Analyse von grösseren kommunikativen Einheiten zu ihren Konstituenten und damit in der Hierarchie der sprachlichen Ebenen von oben nach unten fortschreiten sollte, weil das kommunikative Gesamtanliegen die Wahl der einzelnen sprachlichen Mittel motiviert" (Hoffmann op.cit., 62).

Hoffmann ønsker å trekke ut de viktigste distinktive trekkene på de ulike språklige nivåene i "nedadstigende linje" fra makrostrukturer via syntaks og leksikon til morfemer og grammatiske kategorier.

Et annet eksempel er Ralph (1980), som undersøker hvor mye av det språket som anvendes for å beskrive et gitt emne, er bundet til dette fagområdet (i dette tilfelle arkeologi). Også hans utgangspunkt er tekster og deres innhold. Målet er å nå "ikke-AS"-ordene som tekstene inneholder, og se hvor fagspesifikke de er.

Det typiske i disse eksemplene er å ta utgangspunkt i en tekstmengde, og dele dem inn i FS-tekster og AS-tekster, i det ene tilfelle ved å registrere lingvistiske trekk på alle nivåer, som Hoffmann gjør, eller ved å konsentrere seg helt om ordene, som Ralph gjør.

Ralphs fremgangsmåte forutsetter at språkbrukeren (enten han/hun er fagmann innen teknolekten eller ikke) intuitivt kan skille mellom term og ikke-term. Som vi senere skal komme inn på, er det en del ting som tilsier at vi kan tilskrive språkbrukeren denne kompetansen som del av hans/ hennes språklige intuisjon.

Den syntetiske metoden går i hovedsak ut på å ta utgangspunkt i mindre enheter og se hvordan de fungerer ved å se dem i større sammenhenger (for eksempel tekster). Et eksempel på det er Laurén et al (1985). Her er 
utgangspunktet syntaktiske og leksikalske enheter (som f.eks. verbtyper og verbroller). Man ønsker å unders $\varnothing$ ke om disse enhetene korresponderer eller opptrer sammen med tilstedeværelsen av terminologi, dens frekvens i tekster, termers lengde, hvilken struktur termene har, og deres rolle i diskursen. Ut fra dette søker man ad heuristisk vei å oppnå presiseringer og omprøvninger av hva som skal studeres.

Også i Laurén $(1984,4)$ fremheves det at i praksis må delene stuktureres først, fordi vi ikke kjenner dem.

Et annet eksempel er Roald (1986a). Roald foreslår en definisjon av FS ut fra TL, og ser på tekster som en konkret realisering av terminologi. Utgangspunktet er termene, eller mer presist det hierarkiske systemet av begreper som termene innen et fagområde representerer. En fagtekst utsier primært noe om verden ved hjelp av begrepshierarkiet $i$ angjeldende fag, og representerer en diskurs over dette hierarkiet. Summen av de aktualiserte semantiske, morfologiske, leksikalske og syntaktiske virkemidlene i denne type diskurs utgjør det Roald vil karakterisere som FS (Roald op.cit., 183).

Hoffmann (1984) søker å kombinere analytisk og syntetisk metode ved å ta utgangspunkt i terminologien ("compilation of special vocabularies"), morfologisk og semantisk analyse av termenes komponenter (analytisk metode). Deretter tar han utgangspunkt i morfologiske og grammatiske kategorier, og ser hvordan de korrelerer med større enheter som kollokasjoner, fraser og setninger. Deretter studeres frasestrukturer, setningstyper og setningsmønstre (syntetisk metode). Samtidig holder han fast ved at det er teksten som strukturell og funksjonell enhet som er det sentrale utgangspunkt, og som danner grunnlag for å identifisere makrostrukturer, og at frekvente trekk er styrt av syntaktisk kohesjon og semantisk koherens (Hoffmann op.cit., 35f).

Den semasiologiske metode går grovt sett ut på å ta utgangspunkt i det språklige uttrykk og analysere språklig innhold. Dette er den gjengse metoden innen tradisjonell leksikografi (jf Zgusta 1971). Man tar leksemets uttrykksside (oppslagsordet pluss dets bøyningsparadigme) som utgangspunkt, og søker å kartlegge leksemets denotative og konnotative sider (semanalyse og angivelse av sentrale bruksbetingelser).

I FS-sammenheng vil en slik metode i praksis ha tekster som utgangspunkt, og man ekserperer (trekker ut) ord og uttrykk som ser termaktige ut (Riiber 1981). Man kan f.eks. også benytte seg av datamaskinen og 
sammenlikne en teksts ordformer med et vokabular som man på forhånd har definert som allmennspråklig.

Et stort problem med denne metoden er at AS-leksikonet alltid vil ha en viss grad av polysemi og homonymi. Fortløpende ordformer i tekster kan ha samme uttrykk i AS og i FS, men representere et faglig begrep innen ett (eller flere) fagområde(r) og derfor være en del av en FS-variant. Klassiske eksempler er fysikkens begreper som kraft, energi og effekt.

Dette tyder på at man ikke uten videre ut fra det språklige uttrykket kan se hva som er termer og hva som ikke er det.

Et annet problem, som TL lenge har vært svært oppmerksom på, er at den semasiologiske metoden ofte fører til at de termer man ekserperer representerer et ufullstendig begrepssystem, og at huller i systemet ikke kan oppdages. Hvis man stiller seg spørsmålet om hvilke termer som mangler i en fagspråksordbok, vil man ikke ut fra denne metoden kunne gi noe svar.

Disse svakhetene har man for lengst innsett i terminologilæren, hvor den onomasiologiske metoden er dominerende. Den tar utgangspunkt i det språklige innholdet for å kartlegge det språklige uttrykket (jf Wüster 1985, 1, Picht et al 1985, 36, Rondeau 1982, 11).

I TL går metoden ut på først å klargjøre begreper og definisjoner. Deretter settes de sammen i et mest mulig velordnet system, slik at man for eksempel kan se hvilke begreper som ligger nær hverandre i systemet (dvs som har mange karakteristiske trekk felles), og som det dermed er viktig å holde adskilt. Dette danner så grunnlaget for termdanning, som ideelt sett skal bygge på et fullstendig begrepssystem. Slik sikrer man seg at ikke huller oppstår, og at terminologien blir systematisk og entydig (for kort oversikt over begrepssystemer, jf Rangnes 1988, 24f).

Eksempler på onomasiologisk metode finner man også i leksikografiens semantiske feltanalyse. Særlig har Triers og Ipsens mosaikkanalogi om betydningsfelt i språkets leksikon hatt stor innflytelse. Leksemer har en tendens til å organisere seg $\mathrm{i}$ helheter som en mosaikk, og danne ensartede betydningsområder (jf Geckeler 1982, 89).

\subsection{Modeller}

La oss se nærmere på noen av de mest sentrale modellene for beskrivelser av FS og forholdet mellom FS og AS (jf også oversikt i Arntz et al 1982, 16ff). 
En av de vanligste modellene er Wüsters horisontale fagspråksinndeling (Wüster 1969, 3):

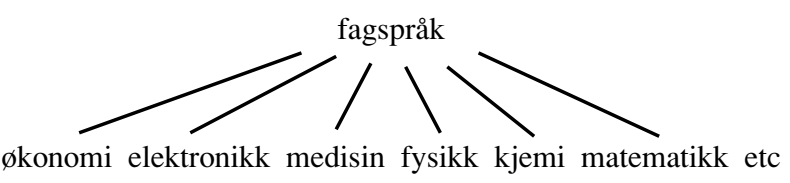

Fagspråk blir da et samlebegrep for en rekke fagområders fagspråksvarianter, kalt teknolekter (jf Laurén 1984). Wüsters modell har flere implikasjoner.

For det første legger modellen opp til at begrepet fagspråk befinner seg på et annet og mer abstrakt nivå enn teknolektene i og med at fagspråk tydeligvis skal være det som er felles for alle teknolektene.

For det andre synes det klart at fagspråk i denne modellen ikke kan eksistere som noe eget språk i kommunikativ forstand. Det er stor uenighet om hvordan man skal forholde seg til dette begrepet, hvilken ontologisk status det skal ha, og hvilken plass det skal innta i beskrivelsen av FS' studieobjekt.

De som har diskutert begrepet, har trukket den konklusjon at jo flere teknolekter man sammenlikner, desto færre blir likhetene mellom dem. Tilslutt står man igjen med tilstedeværelsen av terminologi som eneste fellesnevner (jf Laurén 1984, referert til i Roald op.cit., 179).

Et annet problem som denne modellen tilslører, er forholdet mellom de ulike teknolektene. Hvordan kan de avgrenses fra hverandre? Kan det gjøres på rent formelt grunnlag, dvs ved å se på de ulike teknolektenes kodeegenskaper? Det er lite som tyder på at det er mulig. Ingen har f. eks kommet over en teknolekt hvis fonologiske system er annerledes enn det AS-systemet det tilhører, eller andre teknolekter av samme AS.

Når det gjelder morfologi, er forholdet i store trekk det samme: ingen teknolekter har en særegen morfologi som adskiller den fra andre (kanskje med unntak av visse medisinske teknolekter og kjemisk nomenklatur, jf Sager et. al. 1980, 258).

Det er heller ikke noe som tyder på at teknolektene har særegne grammatiske kategorier som atskiller dem fra AS. Teknolektene bruker også stort sett de samme syntaktiske virkemidlene som AS, selv om visse morfosyntaktiske trekk (som passiv) og visse avledningsmekanismer (som substantivering) i mange teknolekter brukes mer enn i AS, og andre trekk (som imperativ) brukes mindre. 
Vi står da igjen med leksikon som eneste fellestrekk for FS som kategoribegrep: tilstedeværelsen av terminologi, spesielle ord og uttrykk som (i større eller mindre grad) er fremmed for AS.

På den annen side kan vi ikke forestille oss noen teknolekt som ikke bruker allmennspråklige ord og uttrykk. Samtlige teknolekter ikke bare bruker allmennspråklige ord, men det overveldende flertall av ord i fagspråklige tekster er allmennspråklige ord.

Et illustrerende eksempel på dette er Bo Ralphs ordundersøkelse basert på tekster innen fagområdet arkeologi (Ralph op.cit.). Han kom frem til at hele $97,5 \%$ av de ordene han unders $\emptyset$ kte i sitt materiale kunne sies å tilhøre AS-leksikon (Materialet bestod av 3/4 million ordformer og 50 000 morfosyntaktiske ord). Av de 2, 5\% fagbundne ordene var kun $1 \%$ fagord som utelukkende kunne forbindes til en teknolekt. De øvrige måtte tilskrives flere teknolekter. Dette tyder på at teknolektene overlapper sterkt, og at entydig teknolektidentifiserbare termer spiller en svært liten betydning.

Christer Lauréns tekststudier innen prosjektet Svenskt fackspråk viser at $\mathrm{i}$ forholdsvis enkle tekster står de ulike teknolektene mye nærmere hverandre enn i avanserte vitenskapelige artikler i forskningsfronten. I de sistnevnte tekstene synes teknolekten å ha større betydning for utformingen av det språklige uttrykk enn i mer elementære tekster av samme teknolekt (jf Laurén 1987b, 19f).

Nå gir ikke Laurén noen definisjon av hva som er enkelt og hva som er avansert, men det er mulig å tolke dette dithen at enklere tekster er av mer generell art som innføringer i fagområder, mens mer avanserte tekster er av mer spesiell karakter i den forstand at de tar opp og problematiserer spesielle emner.

Dette leder oss inn på en annen vanlig modelltype i FS: vertikal inndeling av FS. Wüster (op.cit.) er også opphavsmannen til den vertikale fagspråksmodellen. I denne type modell settes teknolektene inn på en glideskala hvor AS og FS utgjør de to ytterpunktene:

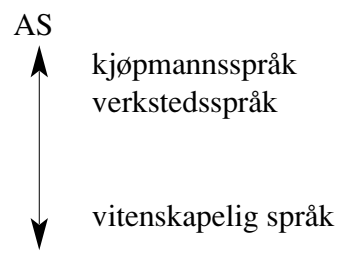


I motsetning til den horisontale modellen gir den vertikale modellen et bilde av forholdet mellom FS og AS. Vi får et klart inntrykk av at overgangen mellom AS og FS er graduell.

En tidlig variant av denne modellen fins hos Baldinger (1952). For å trekke grensene mellom FS og AS deler Baldinger FS etter grad av spesialisering i vokabularet. Han opererer med tre konsentriske sirkler hvor yttersirkelen utgjør AS-vokabularet, midtsirkelen utgjør den delen av vokabularet som brukes når fagmannen henvender seg til lekfolk (f. eks popularisering), mens innersirkelen utgjør den delen som brukes når fagfolk henvender seg til fagfolk (Baldingers sirkler er av praktiske grunner erstattet med rektangler):

\author{
FS-FS-vokabular \\ FS-AS-vokabular
}

\author{
AS-vokabular \\ (Oversatt fra Drozd et al 1973:102)
}

Denne modellen bringer inn en annen variabel i AS/FS-bildet: grenseoppgangen mellom AS og FS varierer ikke bare etter teknolektenes avstand til AS, men teknolektene selv varierer avhengig av språkbrukerne; hvilket forhold det er mellom avsender og mottaker (deres relative sosiale status og deres antatte kunnskap).

Ved Baldingers modell bringes altså det sosiolingvistiske og pragmatiske aspektet ved FS inn i bildet. Som Arnzt et al (op.cit., 20) påpeker, kan modellen også tilpasses et tekstnivå og tjene som nyttig redskap for språkkonsulenter som utfører språklig arbeid av sterkt brukerorientert slag (f.eks translatører, oversettere og terminologer).

Men også Baldingers modell har sine begrensninger. Som Kuhn (1970) har påpekt er det få fagområder som er preget av normalvitenskapelig harmoni. Ulike vitenskaper kan ha ulike paradigmer, og innen én og samme vitenskap har man ofte flere konkurrerende paradigmer. Dette gir seg ofte utslag i uensartet terminologi. I mange tilfeller fins det ulike teorier og innfallsvinkler til ett og samme spesialfelt. I lingvistikken vil f. eks termer som subjekt og fonem ha ulikt innhold avhengig av hvilke modeller og teoretiske forutsetninger man arbeider ut fra. Disse forskjellene kan føre til kommunikasjonsproblemer også innad i et fagmiljø (for diskusjon av lingvistikkens fagspråk jf Beaugrande 1987a). 
Et typisk eksempel på avvikende terminologi er glossematikken innen lingvistikken (jf terminologien i Hjelmslev 1943).

Baldingers modell overforenkler også de faktiske forhold i for stor grad. En del faglige fremstillinger vil bære preg av at de er skrevet for studenter (på ulike faglige nivåer), mens andre er skrevet for fagkolleger. Disse forholdene kommer ikke frem i Baldingers modell.

Blant dem som har forsøkt å bøte på dette er Hoffmann (1976). Hans vertikale inndeling bygger på abstraksjonsgrad og munner ut i 5 nivåer, hvor det første har høyest abstraksjonsgrad og det siste lavest abstraksjonsgrad: 1. den teoretiske grunnforskningens språk 2. de eksperimentelle vitenskapenes språk 3. de anvendte vitenskapenes språk 4. den materielle produksjonens språk og 5 . konsumentenes språk.

Hoffmanns modell er nok bedre egnet til å fange opp en del nyanser som Baldingers modell ikke kan, men de 5 nivåene virker noe umotivert. Det fins ingen gode kriterier for hvordan man skal skille nivåene fra hverandre, og hva som faller inn under dem. Dessuten er begrepet abstraksjon vagt, eller i beste fall flertydig. Videre er det uklart hva som er skillet mellom eksperimentell og anvendt vitenskap. Datalingvistikk for eksempel sees på av noen som anvendt lingvistikk, av andre som eksperimentell lingvistikk.

Det som imidlertid er felles for alle modellene vi har nevt, er at samtlige refererer til begreper som fagområde og fagmann uten å eksplikere hva som ligger i begrepene.

En annen modell som kan sies å falle inn under både den vertikale og den horisontale type, er Ammons (1973). Til forskjell fra de modellene vi hittil har omtalt (som alle tar utgangspunkt i språket), søker Ammon å gripe FS-begrepet ved å ta utgangspunkt i det samfunnsmessige liv, dets sfærer.

Grensen mellom FS og AS faller sammen med to hovedsfærer: arbeidssfæren, som er domenet for FS, og konsumpsjonssfæren, som er domenet for AS (eller mer presist: den delen av AS som står i forbindelse med en FS-variant). Prinsippet om arbeidsdeling er for Ammon den grunnleggende mekanisme for å identifisere teknolektene: jo mer fremskreden arbeidsdelingen er, desto flere (og mer finmaskede) blir teknolektene.

Ammons marxistisk inspirerte modell opererer med tre sfærer som har større eller mindre grad av FS avhengig av hvor mye de har kontakt med konsumpsjonssfæren: 
1. Sfæren for fremstilling av produksjonsmidler (f.eks arbeidsmaterialer). Denne sfæren har ingen direkte forbindelse med forbrukersfæren, og har derfor mye fagspråk. Ord og uttrykk for konstruksjon av verktøymaskiner er derfor ukjente for folk flest.

2. Sfæren for fremstilling av forbruksartikler (som klær, sko, mat etc) har mindre FS, fordi man her står nærmere forbrukersfæren.

3. Sfæren for distribusjon av forbruksartikler (f. eks markedsføring) står nærmest AS. Som eksempler nevnes navn på bilmerker (som VW 1303, FIAT 128, Opel admiral etc). Fra bilhandlernes synspunkt er dette FS, fra kjøpernes synspunkt er det AS.

Ammons sfæremodell kan nok gi interessante opplysninger om forholdet mellom samfunnssektorer og grad av fagspråklighet, men dette vil snarere utggjøre et bidrag til språksosiologien (sociology of language), sett på som en del av sosiologien, enn til sosiolingvistikken, som (som regel) betraktes som en del av lingvistikken (jf Thelander 1984, 32f) og fagspråksforskningen. Ammon sier svært lite om hvordan sfærene virker inn på det språklige uttrykk. Hvis vi ønsker å si noe om FS i lingvistisk sammenheng, må vi la lingvistikken danne utgangspunktet og sette rammene for hva som logisk sett lar seg undersøke. Det synes klart at Ammons utgangspunkt bryter disse rammene. I beste fall kan man si at han ikke nevner noe om hvordan rammene skal settes. Med Ammon beveger vi oss ut av lingvistikkens område og over i sosiologien (som jo også kan studere FS ut fra en sosiologisk synsvinkel).

De fagspråksmodellene vi har omtalt ovenfor har alle det felles at de er opptatt av grensedragninger for å kunne isolere og identifisere et legitimt studieobjekt. Andre fagspråksforskere har innsett at det er svært vanskelig å sette kategoribegrepene FS og AS opp mot hverandre (Sager et al op.cit., 1). I stedet for å fokusere på FS som kategoribegrep kan man studere variantene (teknolektene) og sammenligne dem med andre varianter som man vet mer om: dialekter og sosiolekter. Som fellesbetegnelse for disse variantene har Sager foreslått betegnelsen subspråk (op.cit, 37).

Felles for teknolekter, dialekter og sosiolekter er primært at de tar utgangspunkt i språkbrukerens bakgrunn (geografisk, sosialt og kunnskapsmessig).

På basis av disse tre variablene skisserer Sager opp en pragmatisk rom modell som består av tre akser (se neste side): 
supranasjonale språk

nasjonale språk

regionale varianter

firma, skole,

institusjon

verksteder,

kontorer,

butikker, sosiale

forelesningssalerbruksområder domstoler

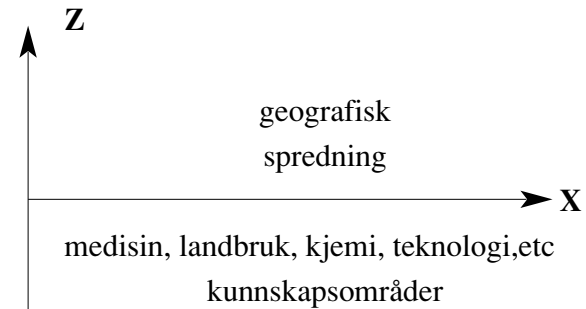

Rom model

Det synes klart at variablene på X- og Y-aksen står nærmere hverandre enn Z-aksens variabler. Som Ammon (op.cit.) påpeker, tenderer industrialisering mot ensrettet produksjon. Terminologilæren er dessuten sterkt opptatt av normerings- og standardiseringsspørmål (som vi senere kommer nærmere inn på). Dette har ført til at studiet av regional variasjon i teknolektene er av forholdsvis beskjedent omfang.

Variasjoner innenfor ulike firmaer, skoler og institusjoner har imidlertid skapt problemer for praktisk normativt terminologiarbeid (jf Roald 1986b).

Hvis man setter de tre variantene opp mot hverandre, vil man lettere bli i stand til å se forskjellene mellom dem.

Sosiolekter og dialekter av samme språk er (som regel) gjensidig forståelige. Ulike teknolekter av samme språk er (som regel) ikke det. Det følger av et definisjonstrekk som går igjen hos alle fagspråksforskere i definisjoner av teknolektbegrepet: en teknolekt er forståelig kun for en bestemt gruppe mennesker i et språksamfunn, og har altså en snevrere forståelsesramme (jf f.eks. Haarala 1983, 40f).

Av forståelighetskriteriet kan vi slutte at sosiolekter og dialekter er varianter som primært innvirker på det språklige uttrykket, og bare i mindre grad på det språklige innholdet, til forskjell fra teknolektene, hvor både språklig uttrykk (primært terminologien) og språklig innhold, dvs dets tematikk, varierer:

"It is emphasized that LSP is different from a sociolect in that it is determined by the topic and not by the interest of a definite social group..." (Hoffmann 1984, 30). 
Sagers modell viser også at teknolektene er resultat av samfunnets kunnskaps- og arbeidsdeling. Den grad av FS som man prøver å beskrive i de vertikale modellene har altså nær sammenheng med grad av fagkunnskap.

En annen interessant kontrast mellom de tre varianttypene er at dialekter og sosiolekter er direkte relaterte til morsmålet i et språk. En språkbrukers dialekt (og flere variabler innen hans språklige register) er lært som integrerende del av hans førstespråkslæring som barn i takt med biologisk modning. Som man vet, tilegnes morsmålet ubevisst, og i stor grad uavhengig av pedagogiske språkopplegg. Det er felles for alle mennesker at de lærer seg morsmålet, og at den læringsprosessen er uavhengig av enkeltmenneskets intelligens.

En teknolekt kan nok i en del tilfeller læres mer eller mindre ubevisst (Beaugrande 1987a, 4), men tilegnes likevel som regel i en utdanningseller arbeidssituasjon. Dessuten er det vel gjennomgående tilfellet at en teknolekt tilegnes på et senere tidspunkt i en språkbrukers liv, etter at dialekt og sosiolektiske registre er tilegnet.

Et annet stikkord i denne sammenhengen er valgmuligheten. Som en følge av språkets sosiale normstyring kan man i mange tilfeller ikke velge hvilken dialekt og sosiolekt man skal tilegne seg, til forskjell fra de mulighetene folk har til å velge teknolekt, fordi en teknolekt ofte har nær sammenheng med et yrkesvalg.

For å summere opp: Det synes å være to hovedtyper av modeller her:

A

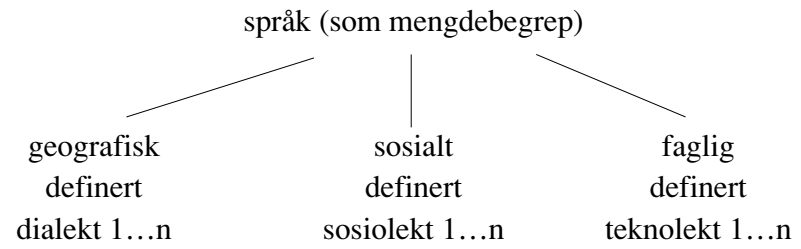

B

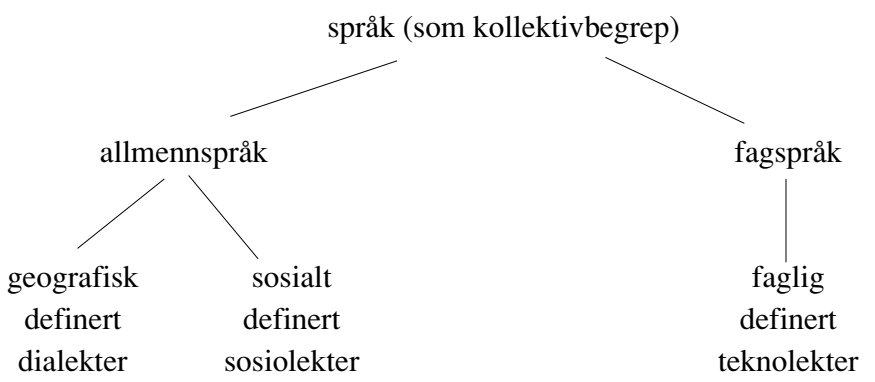


Modell A tar utgangspunkt i språket som et mengdebegrep. Vi får tre varianttyper som skiller seg fra hverandre på ett, flere eller alle nivåer (fonologi, morfologi, syntaks og leksikon). Hvilken betydning det enkelte nivået har, kan veksle: I teknolektene synes leksikalske forskjeller (forskjeller i terminologi) å være det primære særtrekket, mens i dialekter og sosiolekter synes fonologiske, morfologiske og syntaktiske særtrekk å være primære.

Modell B tar utgangspunkt i språket som et kollektivbegrep, og oppfatter også nivået allmennspråk, fagspråk i kollektiv forstand. På lektnivåt virker det derimot som om man betrakter enhetene som mengder: Fagspråket sies å bestå av en mengde teknolekter. I B blir det da en sentral oppgave å rettferdiggjøre det mellomliggende nivået (allmennspråk, fagspråk). og å avgrense de to begrepene overfor hverandre.

Teknolektene i A blir dermed beskrivelsesenheter som er direkte relaterbare til hverandre på samme nivå (og ikke bare indirekte via et mellomliggende kollektivnivå, som i B).

Men ingen av de B-modellene vi har omtalt kan i seg selv gi noe klart svar på hva kollektivbegrepet fagspråk er, og hvordan begrepet skal avgrenses.

\subsection{Definisjonstyper}

Men om antallet modeller innen FS er stort, kan man i like stor grad si et samme om definisjonene som de har gitt opphav til. Uten å gjøre krav på fullstendighet, kan definisjonstypene innen FS deles i fem hovedtyper:

1. de formelt lingvistiske (uttrykksbaserte)

2. de semantiske (innholdsbaserte)

3. de pragmatisk/stilistiske

4. FS som kunstig språk

5. formålsdefinisjoner

Flere av definisjonene vil kunne falle i flere av kategoriene, for eksempel vil pragmatisk/stilistiske definisjoner ofte også ha innslag av formål.

De formelt lingvistiske tar den språklige formen som definisjonsgrunnlag, og kan dermed sies å ha et semasiologisk preg. Et typisk eksempel er Hoffmann, som karakteriserer FS som "a complete set of linguistic phenomena" (Hoffmann 1979, 16). Også hos Haarala $(1983,41)$ og Ralph $(1980,164 f)$ danner formen utgangspunktet. Som vi allerede har påpekt kan ingen teknolekt identifiseres på rent formelt grunnlag. 
De semantiske definisjonene tar ofte utgangspunkt i verbets seleksjonsregler. Ved hjelp av spesielle begrensninger på disse (dvs hvilke mulige semantiske roller som deles ut av V i S) mener man å kunne etablere en sublanguage grammar Et typisk eksempel er Sager (1982).

Dette kan muligens være en fruktbar innfallsvinkel hvis man innen et identifiserbart subdomene kan etablere et sett av systematiske trekk som gjelder for hele domenet, og ikke bare idiosynkratiske trekk som er bundet leksikalsk til det enkelte verb, som for eksempel Katzs skille mellom markers og distinguishers (jf Katz et al 1963).

De pragmatisk/stilistisk pregede definisjoner av FS er særlig fremtredende i tekstlingvistisk orienterte retninger i lingvistikken. Et sentralt eksempel er Pragskolens functional speech analysis (jf Hoffmann 1984, 30ff). Denne retningen er sterkt opptatt av analyse og klassifikasjon av tekster. Tekstanalysens mål er å identifisere kommunikasjonssfæren, tekstens tema, grad av spesialisering og forfatterens behandling av temaet (deskriptivt, evaluerende, klassifiserende, etc).

Etter hvert er denne retningen blitt koplet sammen med begrepet register (Halliday et al 1964) og har fått fotfeste innenfor FS-forskningen (Turner 1973, Halliday 1969).

Innen dette forskningsparadigmet er man stort sett enige om at registre primært slår ut på leksikon, særlig terminologien. FS-varianter, spesiell terminologi og syntaktiske trekk fremkommer som et valg språkbrukeren foretar basert på tekstens tematikk, og kan uttrykkes kvantitativt ved hjelp av statistiske parametere. Man kan for eksempel ta settet av mulige kontekster som ett parameter, og settet av diskurstemaer som et annet parameter. Ut fra dette mener man å kunne beregne den statistiske sannsynlighet for tilstedeværelsen av for eksempel en bestemt type terminologi. Et spørsmål som da melder seg, er om sett av kontekster og settet av temaer er variabler som kan studeres uavhengig av hverandre.

I praksis ser det ut til at fagområde betraktes som et logisk primitiv: Gitt området kjernefysikk, så er det en viss (kvantifiserbar) sannsynlighet for tilstedeværelsen av en bestemt type terminologi. Fagområde brukes altså som kriterium. Det er ingenting i veien for å bruke hypoteser som kriterier, men da må hypotesen ha høy grad av gjendrivelighet. Dets status i forskermiljøet må være allmennt akseptert. Hypoteser om hva et fagområde er synes ikke å ha en slik status.

Et av hovedmålene for Pragskolen er å nå de dynamiske elementene som er felles for alle FS-variantene, og som har kommunikativ funksjon. 
Hovedelementet $\mathrm{i}$ deres analyse er den omstridte functional sentence perspective-teorien (jf Kaminski et al 1981).

Et problem med denne typen analyser er at ingen FS-varianter lar seg identifisere utelukkende ut fra kvantitative parametere. Dessuten er flere grunnleggende begreper som dynamikk og funksjonalt setningsperspektiv vage.

Imidlertid har studiet og beskrivelse av vitenskapelig stil resultert i oppdagelsen av mange interessante trekk ved FS, som for eksempel: eksakthet, objektivitet, generalisering, informasjonstetthet, emosjonell nøytralitet, upersonlig stil, entydighet og bruk av definerte tekniske termer, symboler og figurer.

Disse trekkene kan koples med syntakstrekk som: deklarative setninger, bruk av hypotagmer, passiv, infinitiv og partisipper, upersonlige konstruksjoner og bruk av nominale attributter.

Men, som Beaugrande påpeker, viser undersøkelser at svært få stilistiske faktorer er entydige indikatorer på en FS-variant, for ikke å snakke om FS som kollektivbegrep. Svært mange trekk er idiolektbaserte, og er derfor avhengige av den enkelte språkbruker (Beaugrande 1987b, 3).

Andre har prøvd å definere FS som en type kunstig språk (Galinski et.al. 1986). Denne koplingen er forståelig. Hvis vi ser nærmere på egenskaper ved kunstige språk, oppdager vi at FS har mange trekk fra kunstige språk (jf Sager et.al. op.cit., 41): Kunstige språk brukes for å beskrive eller klassifisere, ikke vekke følelser eller skape sosial kontakt. Deres hovedmål er å oppnå entydighet, dvs unngå homonymi, synonymi og polysemi. Regler for kombinering og bruk av symboler er etablert bevisst med entydighet og uttrykksmessig økonomi for øye.

Hensynet til logisk entydighet og klarhet i vitenskapelig fremstilling var også et overordnet mål for de logiske positivistene ved universitetet $\mathrm{i}$ Wien på 1920-tallet. Deres mål var å forene alle vitenskaper under ett, og utarbeide et kunstig idealspråk for en enhetsvitenskap. Et av hovedmålene var å utarbeide entydige vitenskapelige basisbegreper for dette idealspråket. Ingen naturlige språk er i stand til å gjengi "virkeligheten" på en entydig og klar måte. I de logiske positivistenes idealspråk skulle hvert enkelt uttrykk ha en enkelt betydning. Dette skulle kunne beskrives, enten direkte eller ved reduksjonisme, ved hjelp av relasjonen mellom uttrykket og objektet eller mengden av objekter som uttrykket stod for i den utenomspråklige verden. Setninger skulle reduseres til atomiske 
protokollsetninger (proposisjoner) som skulle ha en en-til-en-korrespondanse med "positive" (verifiserbare) fakta i verden.

Vi skal ikke gå inn på de problemer som verifiserbarhetskriteriet skapte for de logiske positivistene. Men ett av hovedproblemene man møtte var følgende: Det er prinsipielt mulig å konstruere et infinitt antall forskjellige logiske kalkyler som alle har sine fordeler og ulemper avhengig av hva de skal brukes til. Det er ikke mulig å finne objektive kriterier for å velge ut et "idealspråk" blant disse kalkylene (jf Lyons 1977, 140).

Dessuten er det klart at påstandskalkylen og predikatskalkylen er utilstrekkelige for beskrivelse av mange fagområder. Jus er et eksempel på en vitenskap som har mange begreper som sprenger grensene for predikatskalkylen. Begreper som "plikt", "påbud" og "forbud" krever en utvidelse av proposisjonal- og predikatskalylen over i den type modallogikk som kalles deontisk logikk (Lyons 1977, 823ff).

Når dette er sagt er det imidlertid ingen tvil om at logiske formalismer er nyttige redskaper for tanken, og deres fordeler når det gjelder entydighet og økonomi gjør dem svært nyttige i fagspråklige sammenhenger. Dessuten har formalismene ofte den fordel at de er internasjonale og kan fungere som et vitenskapelig lingua franca.

En annen viktig egenskap ved kunstige språk er at de er parasittiske på naturlig språk i den forstand at de forutsetter eksistensen av naturlig språk. FS fremstilles ofte på analog måte: Picht fremhever at AS har autonom eksistens, mens FS er avhengig av AS (Picht et.al. op.cit., 3).

Sammenligningen mellom FS og kunstige språk er nok interessant, men Beaugrande har nok rett $i$ at begrepet naturlig språk ikke er godt nok definert i lingvistikken. Dessuten kan vel kunstige språksystemer bare i perifere tilfeller sies å utgjøre en hel FS-variant (Beaugrande op. cit., 3).

Formålsdefinisjoner har vært, og er fremdeles, meget sentrale i FSforskningen. Det vitner også termen language for special purposes om. Pichts definisjon er typisk: "LSP is a formalized and codified variety of language used for special purposes...." (Picht et.al.op.cit., 3).

Svært mange definisjoner har et større eller mindre innslag av formålsangivelse i sine definisjoner. Også hos Hoffman står dette begrepet sentralt. Han definerer FS som "a complete set of linguistic phenomena occurring within a definite sphere of communication and limited by specific intentions of its users, topics and conditions" (Hoffmann 1976, 170). 
Hvis vi ser på lingvistikkens forhold til begrepet formål i definisjoner av språk, ser vi at det svært sjelden dukker opp som trekk i definisjonene. I mange tilfeller tas det enten for gitt, eller det ekskluderes bevisst (Beaugrande op.cit.).

Et unntak er vel Austins talehandlingsteori, og Grices teori om konversasjonsmaksimene, som blant andre Sager har arbeidet videre med i FSsammenheng (jf Sager et.al. op.cit., 87ff). Sagers eksplikeringsfors $\varnothing \mathrm{k}$ av begrepene intensjon, talehandling og tema, kan muligens være en fruktbar vei å gå for å nå frem til nye innsikter i FS-begrepet.

Som denne oversikten forhåpentlig viser, har man strevet lenge med å gi et klart bilde av FS-begrepet uten å lykkes helt. En mulig forklaring på dette kan være å finne i den dominerende begrepsoppfatningen innen FS, og særlig innen TL: Et begrep skal være uttømmende i den forstand at det skal bestå av karakteristiske, nødvendige og tilstrekkelige trekk. ${ }^{1}$ Det-

'Forholdet mellom, og eksplikeringen av begrepene "karakteristiske", "nødvendige" og "tilstrekkelige" trekk er uklar i terminologilæren. Tolkningen av disse begrepene er vanskelig og omstridt. Jeg har prøvd å tolke begrepene slik:

$$
\begin{aligned}
& \mathrm{T}=\text { tilstrekkelige trekk } \\
& \mathrm{K}=\text { karakteristiske trekk } \\
& \mathrm{N}=\text { nødvendige trekk }
\end{aligned}
$$

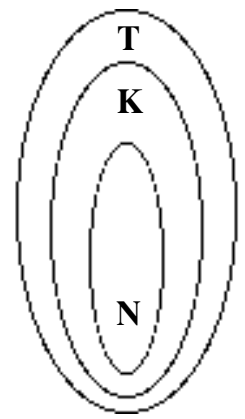

Sirklene oppfattes mengdeteoretisk: Mengden av de nødvendige trekkene er inkludert i mengden av de karakteristiske trekkene, og mengden av de karakteristiske trekkene er inkludert i mengden av de tilstrekkelige.

De nødvendige trekkene er de som må være tilstede for at et begrep ikke skal falle fra hverandre (for eksempel trekket at et gulv må være laget av et fast materiale). De karakteristiske trekkene kan, men behøver ikke, være nødvendige (for eksempel trekket "å kunne fly" som karakteristisk, men ikke nødvendig trekk ved begrepet "fugl").

Det synes mulig å tolke de karakteristiske trekkene ved i alle fall visse begreper i retning av prototyper, dvs folks typiske mentale forestillinger (som for eksempel hypotesen om at en fugl som flyr er en del av vårt typiske bilde av en fugl).

De tilstrekkelige trekkene er kanskje de mest problematiske. Det ser ut til at identifiseringen av trekk betraktes som induktive generaliseringer over mengder av referenter. Den sterkeste påstanden om tilstrekkelige trekk er at de skal kunne predikere alle de situasjoner, eller alle de bruksbetingelser, som rettferdiggjør bruken av et begrep.

Dette er teoretisk mulig hvis man kan beskrive uttømmende alle referenter fra $\mathbf{1}$ til $\mathbf{n}$ i en lukket mengde. Men siden de begrepene man vanligvis opererer med har en infinitt ekstensjon, kan ikke de tilstrekkelige trekkene identifiseres. Dette har for eksempel Popper illustrert (det såkalte induksjonsproblemet 1980:27ff). 
te må vel da også gjelde for begrepet fagspråk. Når dette ikke synes å være mulig kan det være fristende å slutte seg til Roalds konklusjon:

"Vårt poeng er at det er verken fyldestgjørende, hensiktsmessig eller mulig å gi en totaldefinisjon av begrepet "FS" med basis i språklige og tekstuelle trekk (f. eks. tekstkonstitusjon)" (Roald 1986a, 180).

Kanskje begrepet FS ikke har noen "nødvendige og tilstrekkelige trekk" som tilsammen utgjør begrepet FS. Kanskje ingen av de karakteristiske trekkene ved FS ( $\varnothing$ konomi, entydighet, emosjonell nøytralitet, bruk av kunstig språk, nominalisering, etc.) er nødvendige, men at noen, eller flere (i tilfelle hvor mange?), må være tilstede samtidig (uten at det er de samme hver gang) for at begrepet skal kunne opprettholdes. Resultatet blir da at man får grader av FS, og at man kan finne prototypiske FS med svært mange karakteristika tilstede, og mindre typiske, hvor færre trekk er tilstede.

Wierzbicka uttrykker disse egenskapene ved begrepet "begrep" slik:

"The essential part of the concept suggested here is not a set of neccessary and sufficient features an object must have to qualify as a denotatum of a given concrete noun; rather, it is the smallest set of features which, taken together, ensure that any object which has them will be generally recognized as a member of the category in question" (Wierzbicka 1985, 60).

Som Rosch (1973) har påvist gjennom psykologiske eksperimenter, oppfattes evnen til å fly som et essensielt og typisk trekk ved fugler, til tross for at trekket ikke er et nødvendig trekk ved fugler (det er flere fuglesorter som ikke kan fly, men som likevel klart faller inn under begrepet fugl). Likevel må selv den mest rudimentære definisjon av fugl referere til trekket.

Er så begrepet fagspråk av samme type som begrepet fugl i denne sammenhengen? Ut fra det vi hittil har sagt tyder alt på at de syntaktisk/ stilistiske trekkene ved FS er karakteristiske uten å være nødvendige. Det er altså selve kombinasjonen av visse trekk i visse sammenhenger som er nødvendige, snarere enn trekkene selv. Høy grad av nødvendighet synes derimot følgende trekk å ha:

- tilstedeværelse av terminologi

- det å være spesiell kommunikasjon for en gruppe mennesker

- eksistens av en spesiell type kunnskap som grunnlag for FSkommunikasjon. 


\section{Hvilket forhold er det mellom FS og TL?}

Ingen synes å være i tvil om at FS og TL har svært mye med hverandre å gjøre, men synet på forholdet mellom dem varierer. Vi skal i denne sammenhengen ikke gi noen detaljert beskrivelse av terminologibegrepets grunntrekk, men vurdere to av begrepets betydninger (jf Rondeau 1982, 1f): Terminologi er for det første en egen disiplin med studieobjekt og teoretisk fundament; for det andre er terminologi et sett av metoder og retningslinjer for å utføre terminologisk arbeid (terminologi er selvsagt også en liste av termer innen et fagområde).

Det er altså her snakk om terminologi i teoretisk og i praktisk forstand.

Med disse to terminologibegrepene som utgangspunkt kan vi tenke oss fire mulige svar på spørsmål 3:

1. TL er en del av FS.

2. FS er en del av TL.

3. TL er autonom.

4. FS og TL er likeverdige, men gjensidig avhengige.

Hoffmann fremholder at TL logisk sett er en del av FS, men at TL i terminografisk praksis er autonom. Han begrunner dette med at TL har egne nasjonale og internasjonale terminologiorganer (som ISO, Infoterm, Termia, DIN, etc) (Hoffmann 1985, 8).

Han fremhever også det faktum at de mest fremtredende terminologer var (og kanskje også er) opprinnelig ikke-lingvister, et argument som går igjen hos flere terminologer (jf Picht et al op.cit., Spiegel 1985).

Det sistnevnte argumentet kan ikke sies å være særlig tungtveiende, fordi både den tysk-østerrikske Strukturale und Funktionale Wirtschaftslinguistik på 30-tallet, og Wüster, den dominerende teoriutvikleren i TL, var sterkt påvirket av de strukturalistiske strømningene i lingvistikken i Europa. Både Saussures langue/parole-skille, Triers og Weisgerbers teorier om leksikalske felt (Geckeler 1982, 100ff), og Pragskolens fonologiske systemer har satt tydelige spor etter seg i Wüsters arbeider. Dette ser man tydelig i hans terminologiske språktegn, hans semantiske trekkanalyse og hans hierarkiske fremstilling av terminologiske begrepssystemer (Wüster 1985).

En vanlig grenseoppgang mellom FS og TL er at TL begrenser seg til studier av fagspesifikke sektorer av leksikon, mens FS arbeider med større enheter i FS-varianter, som morfo-syntaktiske trekk, fraser, setningstyper, paragrafer og tekster:

"---one section of LSP comprises special lexis - this is the central domain of ter- 
minology." (Picht et al op.cit., 22)

Et sentralt kriterium i dette skillet er at en terminologisk enhet representerer ett begrep. Begrepet er altså et sentralt studieobjekt for TL (jf Picht 1985c), og er en av årsakene til valget av den onomasiologiske metode.

Men forskningen har vist at det er svært vanskelig å opprettholde dette skillet. Studier i FS-fraseologi (jf Picht 1987) viser at ordsekvenser kan sies å representere ett begrep i noen tilfeller, og flere begreper i andre tilfeller. Det har vært vanskelig å finne gode praktiske og anvendelige skillekriterier her.

I alle fall synes skillet mellom TL og FS langs leksikon vs større enheter å stimulere til studier og systematiseringer av fagspråklig leksikon i isolasjon. Slike studier er ikke mulig uten å ta hensyn til de tekstene leksikonet brukes i. Det er heller ikke særlig fruktbart å foreta slike analyser uten å se dem på bakgrunn av de faglige institusjoner og miljøer som er utøvere av denne terminologien.

Et annet skille går på det normative vs det deskriptive. TL har alltid hatt en meget sterk tradisjon innenfor normering og standardisering. Alle de terminologiorganene vi har nevnt er primært normeringsorganer. Hvis målet i praktisk terminologiarbeid er "the improvement of specialized communication in nearly all spheres of science and technology" og "the international unification of terminologies" (Hoffmann 1985, 8), så følger det at TL må være normativ av natur, og at den dessuten må ha den nødvendige autoritet til å utføre sine oppgaver.

Men for at det sistnevnte skal være mulig, må den dessuten også være deskriptiv (og i størst mulig grad også forklarende) i sitt grunnlag. Deskriptive oppgaver som brukeranalyse og undersøkelser av terminologibruk i tekniske og vitenskapelige tekster og diskurser bør derfor stå sentralt i TL.

Vi kan ut fra dette med like stor rett hevde at FS logisk sett er en del av TL. Dette synes å være Roalds konklusjon. Han definerer FS med utgangspunkt i TL:

"Ethvert fag (...) reflekteres i et begrepshierarki bestående av ulike begrepssystemer som forholder seg til hverandre etter bestemte kriterier. Hvert begrepssystem består igjen av ulike begreper som forholder seg til hverandre etter bestemte kriterier. For å gjøre begrepene kommunikable anvendes språkets uttrykksside, nærmere bestemt leksikon (hvilket ikke ekskluderer morfo-syntaktiske aspekter ved termdannelse). For å utsi noe 
om begrepshierarkiet konstitueres det en tekst, ---. Denne teksten representerer en diskurs over et faglig begrepshierarki. Summen av de aktualiserte semantiske, leksikalske og syntaktiske virkemidlene i en slik diskurs vil konstituere det vi bør betegne som FS" (Roald 1986a, 183).

Som så mange andre unge vitenskaper som kjemper for å etablere seg som egen disiplin, strever TL etter autonomi. Dette ser vi også tydelige tegn på i dets litteratur. For eksempel behandles begrepet begrep i TL som om det er vesensforskjellig fra begrepet begrep i AS, til tross for at man ikke klarer å trekke et klart skille mellom FS og AS.

Det understrekes sterkt at et begrepssystem ikke må sees $\mathrm{i}$ isolasjon (noe det heller ikke kan i AS). Det som mest skiller terminografiske fra ikke-terminografiske begrepssystemer er vel at de førstnevnte er mer velorganiserte enn de sistnevnte. Men dette er en gradsforskjell snarere enn en vesensforskjell. Det fins mange begrepssystemer, både innenfor teknologi og vitenskap, som er både vage og inkonsistente (noe som blant annet kan indikere fagets vitenskapelige allmenntilstand). Vaghet og kollisjon mellom data og system er vel problemer som empirisk baserte systemer (systemer som søker å klassifisere verden rundt oss) i større eller mindre grad møter, til forskjell fra de formallogiske systemene, som kan operere uavhengig av empiriske data. Når grensene mellom vitenskap og ikke-vitenskap kan være uklare, er det også naturlig at grensene mellom terminologi og ikke-terminologi vil kunne være det.

Når det gjelder de 3 første alternativene ovenfor (i begynnelsen av 4) kan vi konkludere med at vitenskapelig teori og praksis spriker i terminologilæren: Den vitenskapelige teorien ville tilsi løsning 1 eller 2, mens terminografisk praksis går i retning av 3 .

Den 4. muligheten er at TL og FS er to gjensidig avhengige sektorer av en vitenskap.

På tross av TLs understrekning av at begrepssystemer ikke må sees i isolasjon, vil autonomiløsningen disponere for nettopp dette. Systemet forankres kun i et fagområde, uten at fagområde defineres klart (eller defineres ikke i det hele tatt). Det er nærmest begrepsrealisme å tro at ethvert vitenskapelig og teknologisk fagområde har et velordnet (sett av) begrepssystem(er), og at terminologiens oppgave er å avdekke dette systemet/disse systemene.

Vi kan sammenlikne forholdet mellom FS og TL med forholdet mellom automatisk syntaktisk analyse (ASA) og leksikologi. Man innser idag i stadig større grad behovet for et velorganisert leksikon som en vik- 
tig komponent i ASA. Dette skyldes i stor grad sammenkoplingen mellom ASA, kunstig intelligens og maskinoversettelse. Man er for eksempel begynt å forske i hvordan leksikondefinisjoner kan gjøres tilgjengelige for datamaskinell behandling i automatiske analysesystemer (jf Pustejovsky 1988).

Det er vel liten grunn til å anta at ikke denne utviklingen vil gjøre seg gjeldende også innenfor FS (hvor syntaksanalyse også utgjør en sentral del) og TL.

Hvis de terminologiske leksika faktisk er så velorganiserte som TL påstår, skulle forholdene ligge spesielt vel tilrette for en slik symbiose på FS/TLs område.

Dette skulle vel peke i retning av løsning 4, hvor AS og TL i praksis er likeverdige, og ikke står i noe overordnet/underordnet forhold til hverandre.

Hvis produktet av terminologisk praksis (også kalt terminografi) er velorganiserte og internasjonalt standardiserte terminologier, så kan ikke dette i kommunikativ forstand sees på som noe "ferdig produkt". Kommunikativt blir det først når det brukes systematisk i FS-tekster. Vi kan gjerne se på de terminografiske systemene som teknolektenes kompetanseindikatorer, mens deres anvendelse i FS-tekster er deres utføring. Fordi kompetanse og utføring hører sammen, er det like umulig å isolere terminologien fra FS-språkbruk som det er umulig å isolere leksikon fra AS-språkbruk.

Konklusjonen må da bli: På samme måte som leksikografien og "resten av lingvistikken" er gjensidig avhengige av hverandre, så er også TL og FS gjensidig avhengige, noe som tilsier at tekster blir et viktig grunnlag også for TL.

\section{Litteratur}

Ammon, Uriel (1973): Indføring i Sociolingvistik. København: Gyldendals Sprogbiblotek.

Arnzt, REiner og Heribert Picht (1982): Einführung in die übersetzungsbezogene Terminologiearbeit. Hildesheim.

Baldinger, Kurt (1952): Die Gestaltung des wissenschaftlichen Wörterbuchs. I: Romanisches Jahrbuch. Hamburg.

Beaugrande, Robert de. (1984): Text Production. Toward a Science of Composition. Ablex Publ. Company New Jersey.

Beaugrande, Robert de (1987a): Special purpose language and linguistic theory. I: Unesco Alsed-LSP København: Newsletter. vol. 10, no 2 (25).

Beaugrande, Robert de (1987b): Determinacy distributions in complex systems. I: Science, linguistics, language, life. Zeitschrift für Phonetik, Sprachwissenschaft und 
Kommunikationsforschung, 40.

Chomsky, Noam A. (1985): Knowledge of Language. Cambridge.: Praeger.

Dahlberg, Ingetraut (1974): Grundlagen universaler Wissensordnung. München: Verlag Dokumentation.

Drozd, Lubomir og Seibicke, Wilfred (1973): Deutshce Fach und Wissenschaftssprache. Wiesbaden: Oskar Brandstetter Verlag.

Galinski, Christian og Nedobity, Wolfgang (1986): Eine terminologische Daten bank als Managementinstrument. I: Unesco Alsed-LSP Newsletter. vol. 9, no 2.

Geckeler, Horst (1982): Strukturelle Semantik und Wortfeldtheorie. München: Wilhelm Fink Verlag.

Grice, H.P. (1975): Logic and Conversation. I: Cole S. og J.L. Morgan: Syntax and semantics, 3: Speech Acts. New York.

Greimas, Algirdas Julien (1981): Aktanter, aktører och figurer. I: Kaminsky, Jerzy og Laven, Gösta (red.): Textkoherens. Uppsala: Uppsala Slavic Papers.

Haarala, R. (1983): Språkvård och terminologi. I: Språk i Norden. Nordisk språksekretariats skrifter 2 .

Halliday, Michael Alexander Kirkwood (1969): Existing research and future work. I: Language for Special Purposes. London.

Halliday, Michael Alexander Kirkwood, McIntosch, Angus og Stevens, P(1964): The Linguistic Sciences and Language Teaching. London.

Hjelmslev, Louis (1943): Omkring Sprogteoriens Grundlaggelse. København: Festskrift Københavns Universitet.

Hoffmann, Lothar (1976): Kommunikationsmittel Fachsprache. Berlin.

Hoffmann, Lothar (1979): Towards a theory of LSP. I: Fachsprache. 1, 1/2.

Hoffmann, Lothar (1983): Fachtextlinguistik. I: Fachsprache. 2.

Hoffmann, Lothar (1984): Seven Roads to LSP. I: Fachsprache. 1-2.

Hoffmann, Lothar (1985): On the place of LSP Research in Applied Linguistics. I: Fachsprache. 1-2.

Hoffmann, Lothar og Piotrowski, Rajmond Genrichovic (1979): Beiträge zur Sprachstatistik. Leipzig.

Hymes, Dell (1970): On Communicative Competence. Philadelphia.

Jumpelt, R.W. (1961): Die Übersetzung naturwissenschaftlicher und technischer Litteratur. Berlin.

Kaminsky Jerzy de og Laven, Gösta (1981): Tekstkoherens. Nye riktninger $i$ studiet av textens struktur. Uppsala.

Katz, Jerrod Jakob og Fodor, Jerry A. (1963): The structure of a semantic theory. I: Language 39.

Knudsen, Trgve og Sommerfelt, Alf (1957): Principles of Unilingual Dictionary Definitions. I: Reports for the Eight International Congress of Linguistics. Oslo.

Kuhn, Th.omas (1970): The Structure of Scientific Revolution. Chicago: The University of Chikago Press 
Laisiepen, Klaus, Lutterbeck, Ernst og Meyer Uhlenried, Karl-Heinrich (1980): Grundlagen der praktischen Information und Dokumentation. München: K. G. Sauer.

Laurén, Christer (1984): Fackspråk och teknolekter. I: Nordisk tidsskrift for fagspråk og terminologi. 84/1.

Laurén, Christer (1985): Definisjon och forklaring. I: Nordisk Terminologikursus II. Skodsborg.

Laurén, Christer (1987a): Abstracts. 6th European Symposium on Language for Specific Purposes. Vaasa.

Laurén, Christer (1987b): Hur mycket syns jag i facktexten. I: Fackspråk och oversettningsteori. Vaasa.

Laurén, Christer og Nordman, Marianne (1985): Projektet svenskt fackspråk. Bakgrund, mål och korpus. Vaasa.

Lyons, John (1977): Semantics. I og II. Cambridge: Cambridge University Press.

Martinet, André (1955): Economie des changements phonétiques. Bern: Biblioteca Romanica.

Picht, Heribert (1985a): Terminologiens forskningsgenstand og relasjon til andre discipliner. I: Nordisk Terminologikursus II. Skodsborg.

Picht, Heribert (1985b): Leksikografi - terminografi. I: Nordisk Terminologikursus II. Skodsborg.

Picht, Heribert (1985c): Begrepet som sentralt element i terminologilæren. I: Nordisk Terminologikursus II. Skodsborg.

Picht, Heribert (1987): Fachsprachliche Phraseologi - die terminologische Funktion von Verben. I: Terminologie et traduction, 3.

Picht, Heribert og Draskau, Jennifer (1985): Terminology: An Introduction. Universtiy of Surrey.

Platzack, Christer (1977): Substantivsjuka - ett friskhetstecken?. I: Lundastudier i nordisk språkvetenskap. D 12. Lund.

Popper, Karl Raimond(1980): The logic of Scientific Discovery. Hutchinson. London.

Pustejovsky, James (1988): Knowledge Representation and the computational Lexicon. Pisa Summer School. Pisa: Handout Series.

Ralph, Bo (1980): Hur mycket fackspråk er fackspråk? I: Svenskans beskrivning. 12.

Rangnes, Odd Kjetil (1988): Hva skal dingsen hete? Brannslukkingsutstyr på Gullfaks B. En terminologisk analyse. Hovedfagsoppgave ved Nordisk institutt. Universitetet i Bergen. i: Norske Språkdata 19.

Riiber, Theis (1981): Pilotstudie i excerpering af fagsprog. I: Ark. 11. København.

Roald, Jan (1985): Termen - et faglig begreps uttrykksside. I: Nordisk Terminologikursus II. Skodsborg.

Roald, Jan (1986a): Om begrepet fagspråk. I: Romansk fra vest. Bergen.

Roald, Jan (1986b): Terminolprosjektet. Sluttrapport fra et terminologisk prosjekt. Norske Språkdata 11 (rødserie) Bergen: Norsk Termbank.

Rondeau, Guy (1982): Linguistics and terminology. I: Vasa Proceedings of Nordic Seminar on LSP and Terminology. Vasa. 
Rosch, Eleanor (1973): On the internal structure of perceptual and semantic categories. I: T.E. Moore (red.): Cognitive Development and the Aquisition of Language. New York: Academic Press.

Sager, Juan Carlos, Dungworth, David og McDonald, Peter F. (1980): English Special Languages. Wiesbaden: Oscar Brandstetter Verlag.

Sager, Naomi (1982): Syntactic formatting of science information. I: Kittredge, Richard og Lehrberger, John (red): Sublanguage. Studies of Language in Restricted Semantic Domains. de Gruyter. Berlin.

Saussure, F. de (1970): Kurs i allmänn lingvistik. Bo Cavefors Bokförlag. Paris. Budapest.

Spiegel, Heinz Rudi (1985): Fachsprachenforschung und Terminologiearbeit. I: Nordisk Terminologikursus II. Skodsborg.

Stortingsmelding nr 35 (1975-76): Om forskningens organisering og finansiering.

Svindland, Arne Sivert (1985): Om definisjonen av "anvendt lingvistikk". I: Skriftserien. Institutt for fonetikk og lingvistikk. Bergen.

Tauli, Valter (1968): Introduction to a Theory of Language Planning. I: Acta Universitatis Upsaliensis. Uppsala.

Thelander, Mats (1974): Grepp och begrepp i språksociologin. Lund.

Thompson, Laurence C. (1965): A Vietnamese Grammar. Seattle: University of Washington Press.

Turner, G.W. (1973): Stylistics. Hammondsworth: Pelican Books.

Vinje, Finn-Erik (1983): Fagspråk i mediesamfunnet. I: Språk i norden.

Wierzbicka, Anna (1985): Lexicography and Conceptual Analysis. Ann Arbor: Karona Publishers inc.

Wüster, Eugen (1969): Die vier Dimensionen der Terminologiearbeit. I: Mitteilungsblatt fur Übersetzer und Dolmetscher.

Wüster, Eugen (1971): Begriffs- und Themaklassifikationen. Unterschiede in ihrem Wesen und in ihrer Anwendung. I: Nachrichten für Dokumentation. 22, nr 3. Frankfurt.

Wüster, Eugen (1974): Die allgemeine Terminologielehre - ein Grenzgebiet zwischen Sprachwissenschaft, Logik, Ontologie, Informatik und den Sachwissenschaften. I: Linguistics. An international Review. 119. Mouton: The Hague.

Wüster, Eugen (1985): Einführung in die allgemeine Terminologielehre und terminologische Lexicographie. København: The LSP Centre. UNESCO Alsed. LSP Network.

Yates, F.E. og de Beaugrande, Robert (1987): Physics and Semiotics. I: W. Koch (red.): Semiotics and the individual Sciences. Bochum: Brockmeyer.

Zgusta, Ladislav (1971): Manual of Lexicography. Mouton: The Hague. 